\title{
Working condition and their responsibilities: An evaluation of life satisfaction among mall workers
}

See end of the paper for authors' affiliations NEETU SINGH

Department of Human

Development and Family Studies,

Babasaheb Bhimrao Ambedkar

University, LUCKNOW (U.P.)

INDIA

Email : bhu_ns@yahoo.co.in
ABSTRACT : The present study was designed to investigate the working condition and their responsibilities. An evaluation of life satisfaction among mall workers. Objective to assess the interference of occupational stress and corresponding relationship with there life satisfaction in the study subject. Method and material: The cross sectional study was carried out in there of Lucknow city. The study was confined to the male and female mall workers of age group <20->46 years. A total simple size 120 mall workers. Result: The present study was conducted at different malls in Lucknow city. It included 120 male and female workers who work ked in malls.

KEY WORDS: Working condition, Responsibilities, Life satisfaction

- HOW TO CITE THIS PAPER : Srivastava, Shailja and Singh, Neetu (2015). Working condition and their responsibilities: An evaluation of life satisfaction among mall workers. Asian J. Home Sci., 10 (1) : 269-271. 